\title{
Ovine chorionic somatomammotrophin (oCS) production by isolated cotyledon cells from sheep in early and mid gestation: auto-regulation by recombinant oCS
}

\author{
M C F Soares ${ }^{1,4}$, J L Servely ${ }^{1}$, C Puissant ${ }^{2}$, P Bolifraud ${ }^{1}$, \\ M C Lacroix ${ }^{1}$, B Schaeffer ${ }^{3}$ and G Kann ${ }^{1}$ \\ ${ }^{1}$ Unité de Recherches sur I'Endocrinologie du Placenta et de la Périnatalité, Laboratoire de Biologie Cellulaire et Moléculaire, INRA, \\ 78352 Jouy en Josas Cedex, France \\ ${ }^{2}$ Unité de Différenciation Cellulaire, Laboratoire de Biologie Cellulaire et Moléculaire, INRA, 78352 Jouy en Josas Cedex, France \\ ${ }^{3}$ Unité de Biométrie, INRA, 78020 Versailles Cedex, France \\ ${ }^{4}$ Departamento de Ciencias Fisiologicas FURG, 96201-900 Rio Grande (RS), Brazil \\ (Requests for offprints should be addressed to G Kann, UREPP-BCM-INRA, 78352 Jouy en Josas Cedex, France)
}

\begin{abstract}
We report the ability of sheep placental cotyledonary cells, isolated at different periods of pregnancy (40 to 90 days) to produce ovine chorionic somatomammotrophin (oCS) in in vitro culture conditions. This oCS production increased gradually with stage of pregnancy. Endogenous oCS net production by isolated placental cells was increased, in a dose-dependent manner, by addition of recombinant oCS (roCS). This effect was not observed after addition of recombinant ovine growth hormone. The roCS effect was more potent on cells collected during early pregnancy.
\end{abstract}

Specific immunoprecipitation of oCS revealed that roCS treatment was associated with an increased dosedependent incorporation of $\left[{ }^{35} \mathrm{~S}\right]$ methionine- $\left[{ }^{35} \mathrm{~S}\right]$ cysteine. These findings provide evidence that oCS may act in a paracrine/autocrine manner to up-regulate its own production during early gestation. We suggest that this autoregulation may be associated with morphological and functional differentiation of the trophoblast during the growth of the placenta.

Journal of Endocrinology (1999) 161, 289-298

\section{Introduction}

The ovine placenta consists of cells from both maternal and fetal origins. A hormone produced by this tissue is a $22 \mathrm{kDa}$ protein known as ovine chorionic somatomammotrophin (oCS), or placental lactogen (oPL). It is produced by binucleate cells of the fetal trophoblast and was first purified by Handwerger et al. (1974) and Martal \& Djiane (1975). Ovine chorionic somatomammotrophin shares significant structural homology with both ovine prolactin (oPRL - 49\%) and growth hormone (oGH - 28\%) and can serve as a bifunctional hormone by binding to GH or PRL receptors (Chan et al. 1978a, Servely et al. 1983, Colosi et al. 1989, Warren et al. 1990). Production of oCS was first detected in the ovine trophoblast as early as day 16 (d16) of gestation (Martal \& Djiane 1977). It was postulated that oCS was delivered to the maternal circulation by migration of fetal binucleate cells from the chorionic epithelium across the fetal-maternal boundary into the uterine epithelium to form a syncytium (Wooding 1981, Lee et al. 1986), but how oCS is delivered to the fetal circulation has not been defined. Schoknecht and coworkers (1991) suggested that oCS release was controlled differently on the fetal and maternal sides of the placenta. In the maternal circulation, oCS was detected from day 40 to day 50 of pregnancy (Handwerger et al. 1977, Martal \& Djiane 1977) and maximum levels were observed 10 to 15 days prior to parturition (Chan et al. 1978b). In the ovine fetal plasma, oCS concentrations increased until mid gestation and subsequently declined to term (Gluckman et al. 1979, Schoknecht et al. 1992).

Taylor and co-workers (1980) suggested that oCS could act as a growth-promoting agent in early pregnancy. The somatogenic effects of oCS include enhancement of fetal plasma concentration of insulin-like growth factor-I, hepatic glycogen deposition during late gestation and stimulation of the growth of several vital organs in lambs (Fowlkes \& Freemark 1992, Singh et al. 1992, Schoknecht et al. 1996). The conclusions from studies on oCS specific binding remain in question: a specific binding site for oCS in lamb liver has been described by some authors (Freemark et al. 1986, 1988, Pratt et al. 1995), while others have suggested that oCS binds to oGH receptors (Breier et al. 1994, 1994, Klempt et al. 1993). Ovine chorionic somatomammotrophin has been sequenced, cloned and the recombinant form expressed (Colosi et al. 1989). 
Availability of recombinant oCS (roCS) has now made it possible to investigate the specific effects of oCS in sheep (Sakal et al. 1997).

Numerous factors which modulate the concentration of oCS in the maternal and/or fetal circulation include: nutritional status (Brinsmead et al. 1981, Gluckmann \& Barry 1988), serum concentrations of arginine and its derivatives (Handwerger et al. 1978), high density lipoproteins (Grandis et al. 1989), epidermal growth factor (Moore et al. 1984) and arachidonic acid (Huyler et al. 1985). Few studies exist which describe in vitro placental oCS production and/or regulation and generally these works have been short-term experiments (Steven et al. 1980, Rhodes et al. 1986, Rice \& Thorburn 1986, Battista et al. 1990, Morgan et al. 1990). The present study was conducted to characterise oCS production in vitro by dispersed ovine cotyledonary cells collected from days 40 to 90 of gestation. The effects of addition of roCS and recombinant oGH (roGH) on this endogenous oCS production were investigated during early and mid gestation.

\section{Materials and Methods}

\section{Animals}

Twenty-eight ewes from the Préalpes du Sud breed were killed on days 40 to 90 of pregnancy: d40-d49 (4); d50-d59 (4); d60-d69 (7); d70-d79 (7); d80-d89 (6), according to the French recommendations for the use of experimental animals (guideline 04/19/1988). The uteri were immediately removed and the placental cotyledons collected aseptically and washed in Earle's balanced solution $(\mathrm{pH} 7 \cdot 4)$ supplemented with $100 \mathrm{U} / \mathrm{ml}$ penicillin, $100 \mu \mathrm{g} / \mathrm{ml}$ streptomycin and $10 \mu \mathrm{g} / \mathrm{ml}$ gentamycin.

\section{Cell dispersion and culture}

Placental cotyledons were separated from their attachment to maternal caruncles by gentle manual traction. Fetal cotyledons were then excised, minced and incubated for $1 \mathrm{~h}$ at $37^{\circ} \mathrm{C}$ in $100 \mathrm{ml}$ Earle's balanced saline solution containing $200 \mathrm{U} / \mathrm{ml}$ collagenase XI (Sigma, St Louis, MO, USA), $200 \mathrm{U} / \mathrm{ml}$ hyaluronidase (Sigma), $0 \cdot 1 \%$ soybean trypsin inhibitor (Sigma), $0 \cdot 25 \mathrm{mg} / \mathrm{ml}$ DNase I (Boehringer Mannheim, Mannheim, Germany) and 2\% bovine serum albumin (IBF, Villeneuve la Garenne, France). Cells were dispersed by gentle passage through a 20/10 mm cannula and then diluted with $300 \mathrm{ml}$ fresh Earle's medium and filtered through two layers of cheese cloth to remove undigested tissue. Subsequently, the cells were aliquoted into $50 \mathrm{ml}$ polypropylene tubes and centrifuged $\left(200 \mathrm{~g}, 5 \mathrm{~min}, 4^{\circ} \mathrm{C}\right)$. Pellets were collected and washed 4 times by resuspension in $50 \mathrm{ml}$ fresh Earle's medium. The lysis of red blood corpuscles in cell preparations was obtained by dispersion and incubation during
$10 \mathrm{~min}$ in $40 \mathrm{ml}$ ice-cold ammonium buffer $\left(\mathrm{NH}_{4} \mathrm{Cl}\right.$ $155 \mathrm{mM}, \mathrm{KHCO}_{3} 10 \mathrm{mM}$, EDTA $0.01 \mathrm{mM}$ ). The cells were washed twice and filtered through a one-layer filter (25 $\mu \mathrm{m}$; Polylabo, Strasbourg, France). Cell viability was determined by the Trypan blue exclusion method at the end of each period of culture. The cells were incubated at a concentration of $10^{6}$ viable cells $/ \mathrm{ml}$ in Dulbecco's modified Eagle's medium (DMEM)/F12 culture medium (ATGC, Seromed, Champs sur Marne, France) supplemented with $0.5 \%$ bovine serum albumin, $100 \mathrm{U} / \mathrm{ml}$ penicillin, $100 \mu \mathrm{g} / \mathrm{ml}$ streptomycin and $10 \mu \mathrm{g} / \mathrm{ml}$ gentamycin, for $16 \mathrm{~h}$ at $37^{\circ} \mathrm{C}$ (recovery period) under an atmosphere of $95 \%$ air, $5 \% \mathrm{CO}_{2}$. The cells were then centrifuged and resuspended in fresh medium at a concentration of $0.5 \times 10^{6}$ cells $/ \mathrm{ml}$. For metabolic experiments, normal DMEM/F12 was replaced by a DMEM-methioninecysteine-free medium (Biowhittaker, Fontenay-sous-Bois, France) supplemented with $10 \mu \mathrm{Ci} / \mathrm{ml}\left[{ }^{35} \mathrm{~S}\right]$ methionine$\left[{ }^{35} \mathrm{~S}\right]$ cysteine (Pro-Mix, Amersham, Les Ulis, France). Partitioning of cells differed according to the experimental protocol: for RIA and metabolic assays, $2 \times 10^{6}$ cells/well were distributed into 6- and 24-well plastic culture plates respectively (Greiner, Poitiers, France). For RNA analysis, $3 \times 10^{6}$ cells/well were used. The cells were incubated at $37^{\circ} \mathrm{C}$ under an atmosphere of $95 \%$ air, $5 \% \mathrm{CO}_{2}$ for up to $72 \mathrm{~h}$ without change of medium. The time at which cells were plated was designated as time zero of culture. For measurement of the amount of oCS accumulated, the media and cells were collected at time zero and at the end of each period of $8,24,48$ or $72 \mathrm{~h}$. Cells were separated from media by centrifugation $\left(3000 \mathrm{~g}, 10 \mathrm{~min}, 4^{\circ} \mathrm{C}\right)$. For the assay of oCS cellular content, cell pellets were submitted to lysis in $1 \mathrm{ml}$ buffer (Tris $20 \mathrm{mM}, \mathrm{NaCl} 100 \mathrm{mM}$, EDTA $1 \mathrm{mM}$, phenylmethylsulphonyl fluoride $1 \mathrm{mM}$, Nonidet P-40 1\% (Sigma), protamine sulphate $0 \cdot 2 \mathrm{mg} / \mathrm{ml}$ (Merck, Darmstadt, Germany)). For oCS radioimmunoassay (RIA), all media were carefully withdrawn to avoid contamination of cell contents by conditioned medium. Both media and cellular lysates were stored at $-20{ }^{\circ} \mathrm{C}$ until assayed. When we tested the effects of either roCS or roGH on oCS production, 100 or $300 \mathrm{ng} / \mathrm{ml}$ (roCS) and 10 or $50 \mathrm{ng} / \mathrm{ml}$ (roGH), kindly supplied by A Gertler (Jerusalem, Rehovot, Israel), were added in the media before cell distribution.

\section{Radioimmunoassay}

Concentrations of oCS in culture medium and cell lysates were measured by a double antibody RIA already described, using a specific anti-oCS rabbit serum (Lacroix et al. 1996). The sensitivity of the assay was $0 \cdot 25 \mathrm{ng}$ oCS/tube. Intra-assay and interassay coefficients of variation were $6.8 \%$ and $8.0 \%$ respectively. Before analysis of oCS conditioned medium data, values corresponding to the roCS concentrations added in the medium (100 or $300 \mathrm{ng} / \mathrm{ml}$ ) were subtracted from the values assayed. 


\section{Immunoprecipitation and autoradiograph analysis}

Samples of cellular lysates and conditioned media from metabolic experiments were pooled after $24 \mathrm{~h}$ and $72 \mathrm{~h}$ of culture respectively. Pools were concentrated and dialysed on Centriprep-10 concentrators (Amicom, Epernon, France). The protein concentrations from conditioned medium and cell lysates were determined using the method of Lowry-Peterson (Peterson 1977). Equivalent protein amounts were incubated overnight at $4{ }^{\circ} \mathrm{C}$ in $100 \mu \mathrm{l}$ NET-gel buffer (Tris $50 \mathrm{mM}, \mathrm{NaCl} 150 \mathrm{mM}$, Nonidet P-40 $0 \cdot 1 \%$, EDTA $1 \mathrm{mM}$ (pH 8.0), gelatine $\left.0 \cdot 25 \%, \mathrm{NaN}_{3} 0 \cdot 02 \%\right)$ with $5 \mu \mathrm{l}$ rabbit anti-oCS gamma globulin obtained from the specific anti-oCS serum described in the RIA section. This concentration of antibody was tested so as to bind up to $2 \mu \mathrm{g} / \mathrm{ml}$ oCS. The antibody-antigen complex was precipitated after incubation with a purified ovine anti-rabbit gamma globulin $(25 \mu \mathrm{l} ; 24 \mathrm{~h})$ and centrifugation for $15 \mathrm{~min}$ at $17000 \mathrm{~g}$. The pellets were washed twice with $1 \mathrm{ml}$ washing buffer (Tris $50 \mathrm{mM}, \mathrm{NaCl} 100 \mathrm{mM}$, SDS 0.05\%, Nonidet P-40 $0 \cdot 1 \%, \mathrm{NaN}_{3} 0 \cdot 02 \%$ ). The samples and control roCS (20 ng) were analysed under denaturing and reducing conditions in the same SDS-PAGE (16\% acrylamide gels). The gels were stained for $1 \mathrm{~h}$ with Coomassie blue to identify the control roCS band. Then, gels were incubated in a $1 \mathrm{M}$ salicylate solution to increase the signal (Chamberlain 1979), dried during $2 \mathrm{~h}$, and then exposed in a phosphor screen. The intensity of the oCS signal was quantified using a PhosphorImager SF (Molecular Dynamics, Sunnyvale, CA, USA) and the computer analysis program ImageQuant (Molecular Dynamics). The electrophoretic mobility of the labelled bands obtained after immunoprecipitation was compared with that of the control roCS. The specificity of the oCS immunoprecipited band was checked by the addition of increasing amounts of unlabelled roCS to samples before immunoprecipitation and by probing blots with anti-oCS antibody.

\section{Northern blot analysis}

Total cellular RNA was isolated from cells by lysis in $4 \mathrm{M}$ guanidinium isothiocyanate solution using the method of Chomczynski and Sacchi (1987) and modified by Puissant and Houdebine (1990). The amount and purity of the isolated RNA was determined by absorbency at $260 \mathrm{~nm}$. Total RNA of cultured placental cells and of d60 placental tissue as a control $(20 \mu \mathrm{g})$ were submitted to electrophoresis on $1 \%$ agarose gels containing $2 \cdot 2 \mathrm{M}$ formaldehyde and transferred to nylon membranes (Nytran NY $13 \mathrm{~N}$, Schleicher \& Schuell, Equevilly, France). Blots were prehybridised in a $0.5 \mathrm{M}$ sodium dihydrogenophosphate solution $\mathrm{pH} 7 \cdot 2$ containing 5\% SDS, $1 \mathrm{mM}$ EDTA, and $0.5 \%$ non-fat dry milk for $5 \mathrm{~h}$ and hybridised in the same buffer with an oCS cDNA probe (0634) kindly supplied by Genentech Inc., (South San Francisco, CA, USA), labelled with $\left[{ }^{32} \mathrm{P}\right] \mathrm{dCTP}(3000 \mathrm{Ci} / \mathrm{mmol}$; Amersham) for $18 \mathrm{~h}$ at $65^{\circ} \mathrm{C}$. Blots were washed twice for $5 \mathrm{~min}$ in $4 \times \mathrm{SSC}(\mathrm{NaCl} 600 \mathrm{mM}$, sodium citrate $60 \mathrm{mM}, 0.5 \%$ SDS, pH 7.0) at $65^{\circ} \mathrm{C}$. Variation in loading and quality of RNA was checked using radiolabelled $18 \mathrm{~S}$ ribosomal cDNA probe (Raynal et al. 1984). The blots were exposed on a phosphor screen and the generated signal quantified using a PhosphorImager SF (Molecular Dynamics) and the computer analysis program ImageQuant (Molecular Dynamics).

\section{Statistical analysis}

Results from the oCS RIA are given as means \pm S.E.M. and were analysed using the MIXED procedure of SAS software (SAS 1997). The model included fixed effects for stage of gestation (STAGE), treatment (TREAT), time (TIME) and their interactions, and random effects for animal (ANIMAL) and its interactions with TREAT and TIME. All these random effects were tested. As they are significant they were kept in the model and used to test fixed effects. The model used for this experiment was: $\mathrm{Y}_{\mathrm{ijk}(\mathrm{i})}=\mu+\alpha_{\mathrm{i}}+\beta_{\mathrm{j}}+\mathrm{a}_{\mathrm{k}(\mathrm{i})}+(\alpha \beta)_{\mathrm{ij}}+(\beta \mathrm{a})_{\mathrm{jk}(\mathrm{i})}+\gamma_{\mathrm{t}}+(\gamma \mathrm{a})_{\mathrm{tk}(\mathrm{i})}+(\alpha \gamma)_{\mathrm{it}}+$ $(\beta \gamma)_{\mathrm{jt}}+(\alpha \beta \gamma)_{\mathrm{ijt}}+\mathrm{e}_{\mathrm{ijk}(\mathrm{i}) \mathrm{t}}$, where $\mu$, general mean; $\alpha_{\mathrm{i}}$, STAGE effect; $\beta_{\mathrm{j}}$, TREAT effect; $\mathrm{a}_{\mathrm{k}(\mathrm{i})}$, ANIMAL effect nested in STAGE; $(\alpha \beta)_{\mathrm{ij}}$, STAGE*TREAT interaction; $(\beta a)_{\mathrm{jk}(\mathrm{i})}$, TREAT*ANIMAL(STAGE) interaction; $\gamma_{\mathrm{t}}$, TIME

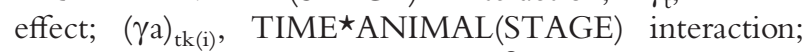
$(\alpha \gamma)_{\mathrm{it}}, \mathrm{STAGE}^{\star} \mathrm{TIME}$ interaction; $(\beta \gamma)_{\mathrm{jt}}, \mathrm{TREAT}^{\star} \mathrm{TIME}$ interaction; $(\alpha \beta \gamma)_{\mathrm{ijt}}$, STAGE`TREAT ${ }^{\star} \mathrm{TIME}$ interaction and $\mathrm{e}_{\mathrm{ijk}(\mathrm{i}) \mathrm{t}}$, residual error. STAGE effects were tested against the variability of ANIMAL(STAGE). TREAT and STAGE*TREAT were tested against the variability of TREAT*ANIMAL(STAGE). TIME and STAGE* TIME were tested against the variability of TIME* ANIMAL(STAGE). STAGE`TREAT*TIME was tested against the residual. A square root transformation of the response variable was used to control heterogeneity of variances. Tests with a $P$ value $<0.05$ were considered statistically significant.

\section{Results}

Characterisation of net oCS production by isolated cotyledonary cells

Evaluation of oCS accumulated in the culture medium and cellular content The amounts of oCS that accumulated in the medium increased gradually with duration of culture and with the stage of gestation from which the cells were collected (Table 1). Due to individual variation, global analysis showed that this increase was significant only among tissues collected between days 40-49 and days $80-89$ of gestation $(P=0 \cdot 017 ; n=28)$. The 
Table 1 Evolution of in vitro oCS net production by ovine cotyledonary cells collected at different stages of gestation. oCS accumulated in the medium and the cellular content were measured at time $0,8 \mathrm{~h}, 24 \mathrm{~h}, 48 \mathrm{~h}$ and $72 \mathrm{~h}$ of culture. Values are the means \pm S.E.M. and are expressed as $\mathrm{ng} / \mathrm{mg} / 10^{6}$ viable cells. The experiments were conducted in sextuplicates

\begin{tabular}{|c|c|c|c|c|c|}
\hline & \multicolumn{5}{|l|}{ Stage } \\
\hline & $\begin{array}{l}\mathrm{d} 40-49 \\
(n=4)\end{array}$ & $\begin{array}{l}\text { d50-59 } \\
(n=4)\end{array}$ & $\begin{array}{l}\text { d60-69 } \\
(n=7)\end{array}$ & $\begin{array}{l}d 70-79 \\
(n=7)\end{array}$ & $\begin{array}{l}\mathrm{d} 80-89 \\
(n=6)\end{array}$ \\
\hline \multicolumn{6}{|c|}{ Medium } \\
\hline 0 & $2 \cdot 20 \pm 1 \cdot 00$ & $4 \cdot 10 \pm 0 \cdot 90$ & $5 \cdot 00 \pm 1 \cdot 00$ & $5 \cdot 20 \pm 1 \cdot 50$ & $9 \cdot 30 \pm 2 \cdot 10$ \\
\hline 8 & $27 \cdot 00 \pm 10 \cdot 90$ & $23 \cdot 70 \pm 9 \cdot 40$ & $9 \cdot 60 \pm 2 \cdot 20^{\mathrm{b}}$ & $33 \cdot 00 \pm 16 \cdot 80$ & $44 \cdot 80 \pm 8 \cdot 40$ \\
\hline 72 & $34 \cdot 50 \pm 18 \cdot 84^{\mathrm{ab}}$ & $73 \cdot 40 \pm 8 \cdot 30^{b}$ & $86 \cdot 10 \pm 29 \cdot 60^{b}$ & $129 \cdot 50 \pm 36 \cdot 40$ & $192 \cdot 20 \pm 37 \cdot 30$ \\
\hline \multicolumn{6}{|c|}{ Cellular content } \\
\hline 0 & $18 \cdot 60 \pm 10 \cdot 60^{b}$ & $34 \cdot 20 \pm 11 \cdot 90^{b}$ & $33 \cdot 40 \pm 10 \cdot 70^{\mathrm{b}}$ & $43 \cdot 90 \pm 10 \cdot 20$ & $66 \cdot 40 \pm 6 \cdot 70$ \\
\hline 8 & $69 \cdot 50 \pm 10 \cdot 60$ & $43 \cdot 80 \pm 3 \cdot 50^{b}$ & $31 \cdot 90 \pm 8 \cdot 10^{\mathrm{b}}$ & $77 \cdot 20 \pm 25 \cdot 90$ & $83 \cdot 70 \pm 23 \cdot 00$ \\
\hline 24 & $13 \cdot 70 \pm 6 \cdot 00^{\mathrm{ab}}$ & $23 \cdot 00 \pm 7 \cdot 50^{\mathrm{ab}}$ & $23 \cdot 00 \pm 8 \cdot 10^{\mathrm{ab}}$ & $53 \cdot 50 \pm 15 \cdot 90$ & $59 \cdot 90 \pm 12 \cdot 60$ \\
\hline 48 & $8 \cdot 80 \pm 3 \cdot 70^{\mathrm{b}}$ & $12 \cdot 10 \pm 5 \cdot 40^{\mathrm{b}}$ & $13 \cdot 40 \pm 4 \cdot 90^{\mathrm{b}}$ & $34 \cdot 20 \pm 11 \cdot 90$ & $42 \cdot 20 \pm 9 \cdot 60$ \\
\hline
\end{tabular}

a,b $P<0.05$ compared with $\mathrm{d} 70-79$ and $\mathrm{d} 80-89$ respectively.

oCS accumulation in the medium was maximal at $72 \mathrm{~h}$ of culture. However, we observed that $59 \%$ of this amount was already released after the first $24 \mathrm{~h}$ of culture.

Cellular content of oCS assayed at time 0 increased significantly between $\mathrm{d} 40$ and $\mathrm{d} 90$ of gestation $\left(18 \cdot 60 \pm 10 \cdot 60 \quad(n=4)\right.$ vs $66 \cdot 40 \pm 6 \cdot 70(n=6) \mathrm{ng} / \mathrm{ml} / 10^{6}$ viable cells respectively; Fig. 1A). Global analysis $(n=28)$ showed that the cellular content of oCS at days 80-89 was significantly higher than that found in the first three stages studied: $\mathrm{d} 40-49(P=0 \cdot 007), \mathrm{d} 50-59(P=0 \cdot 02)$ and $\mathrm{d} 60-69$ $(P=0 \cdot 008)$. The oCS cellular content pattern was similar during culture (0 to $72 \mathrm{~h}$ ) whatever the pregnancy stage considered. The greatest cellular content of oCS was recorded after $8 \mathrm{~h}$ of culture (Table 1). It decreased progressively from $8 \mathrm{~h}$ up to $72 \mathrm{~h}$ for all stages of pregnancy. However, this decrease was less pronounced for later stages.

Total net oCS production by dispersed cells was estimated as the amount the oCS released into the medium and the cellular content at $72 \mathrm{~h}$. In spite of animals' individual variations, oCS production by dispersed cells increased gradually from $\mathrm{d} 40-49$ up to $\mathrm{d} 80-89$ (Fig. 1B).

Analysis of oCS mRNA during cell culture The expression of oCS mRNA by cotyledonary cells collected from placentae between d54 and d69 of gestation was studied by Northern blot at $30 \mathrm{~min}, 8 \mathrm{~h}, 24 \mathrm{~h}$ and $48 \mathrm{~h}$ of culture. Cotyledonary cells in culture contained detectable oCS mRNA of the expected size (Fig. 2A). As the time of culture progressed, oCS mRNAs signals decreased (Fig. 2B). However, a simultaneous decrease in the $18 \mathrm{~S}$ mRNA signal was also observed (Fig. 2C).
Incorporation of $\left[{ }^{35} \mathrm{~S}\right]$ methionine- $\left[{ }^{35} \mathrm{~S}\right]$ cysteine in the oCS by cotyledonary cells Incorporation of $\left[{ }^{35} \mathrm{~S}\right]$ methionine- $\left[{ }^{35} \mathrm{~S}\right]$ cysteine in the oCS was estimated in the medium at $72 \mathrm{~h}$ (maximal accumulation) and in the cellular content at $24 \mathrm{~h}$ (oCS cellular content and mRNA signal were important at this time). The analysis by SDS-PAGE of labelled oCS in the cellular content and media, obtained by specific immunoprecipitation, showed radiolabelled bands which had the same electrophoretic mobility as the control roCS band (Fig. 3; lanes 1 and 4). Specificity of these bands was assessed by addition of increasing amounts of unlabelled roCS to the conditioned medium before immunoprecipitation, which reduced signal intensity and by Western blot detection with an oCS antibody (not shown).

Effects of addition of roCS and roGH on endogenous oCS net production by ovine dispersed cotyledonary cells

Effects of roCS addition on cotyledonary cells in culture Addition of roCS in the culture medium increased significantly the endogenous oCS release in a dose-dependent manner $(P=0 \cdot 0001 ; n=28)$. This increase was always observed for $300 \mathrm{ng} / \mathrm{ml}$ roCS dose, but it was less important on cells collected at the later stages of pregnancy. The effect of $100 \mathrm{ng} / \mathrm{ml}$ roCS dose was not observed beyond d50-59 (Fig. 4). The cellular content of oCS was dose-related to roCS treatment but to a lesser extent than for conditioned medium. Important variability was observed between animals at the same period of gestation (Fig. 5); however, global analysis showed significant effects of roCS treatment $(P=0 \cdot 001$; $n=28$ ). The total endogenous oCS production (medium 

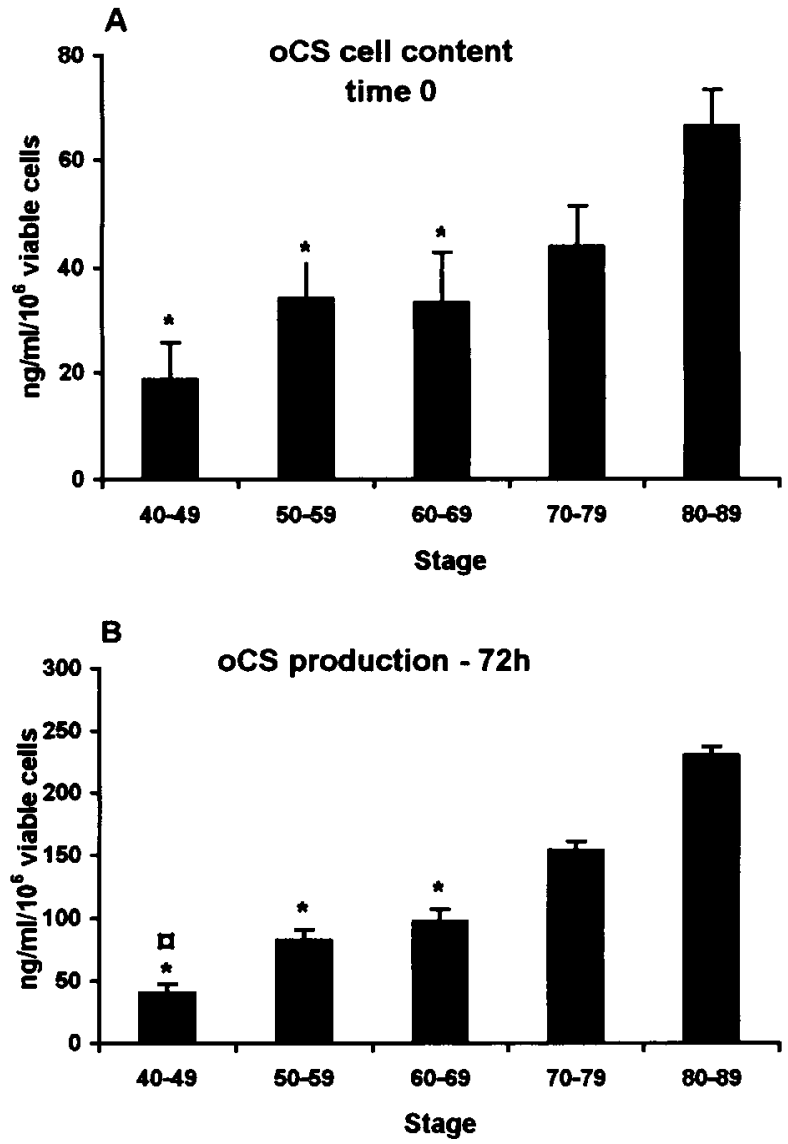

Figure 1 oCS net production by ovine cotyledonary cells collected at different periods of gestation: d40-49 $(n=4), \mathrm{d} 50-59(n=4)$, d60-69 ( $n=7), \mathrm{d} 70-79(n=7)$ and d80-89 ( $n=6)$. (A) oCS cell contents at time zero. The cells were cultured as described in Materials and Methods. (B) oCS net production (addition of media and cellular content) at $72 \mathrm{~h}$ of culture. Values represent the means \pm S.E.M. of oCS production and are expressed as $\mathrm{ng} / \mathrm{ml} / 10^{6}$ viable cells. (\) and $\left({ }^{*}\right)$ represent a significant difference $(P<0 \cdot 05)$ compared with d70-79 and d80-89 respectively.

and cellular content) was significantly stimulated by the addition of either 100 or $300 \mathrm{ng} / \mathrm{ml}$ roCS $(P=0 \cdot 0001$; $n=28$ ).

Immunoprecipitation of radiolabelled oCS $\left(\left[{ }^{35} \mathrm{~S}\right]\right.$ methionine- $\left[{ }^{35} \mathrm{~S}\right]$ cysteine incorporation) in media $(72 \mathrm{~h})$ and cellular content $(24 \mathrm{~h})$ after addition of either 100 or $300 \mathrm{ng} / \mathrm{ml}$ roCS analysed by SDS-PAGE showed a dosedependent increase in the intensity of radiolabelled oCS bands (Fig. 3). However, statistical analysis of the quantified signals $(n=3)$ showed significant differences only in media $(P=0 \cdot 025)$.

Effects of roCS on oCS mRNA Since roCS stimulated endogenous oCS net production, we investigated whether this stimulation occurred at the level of oCS mRNA. This study was carried out between d54 and d69, corresponding
A

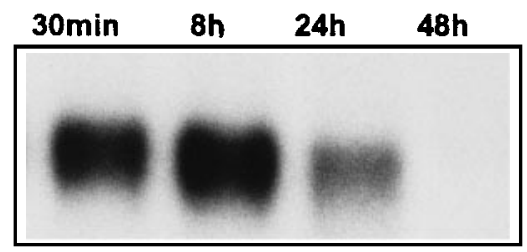

ocs -
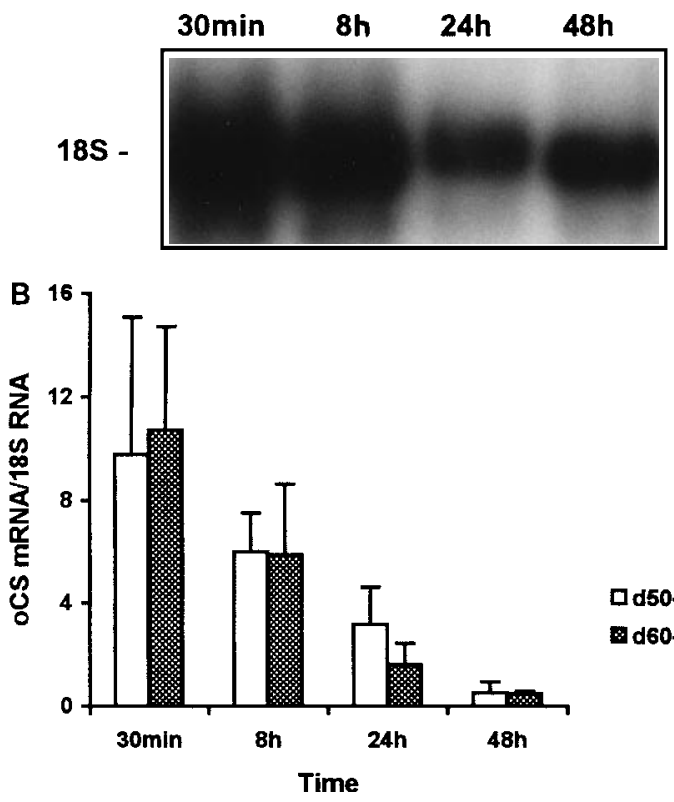

口 d50-59

d $00-69$

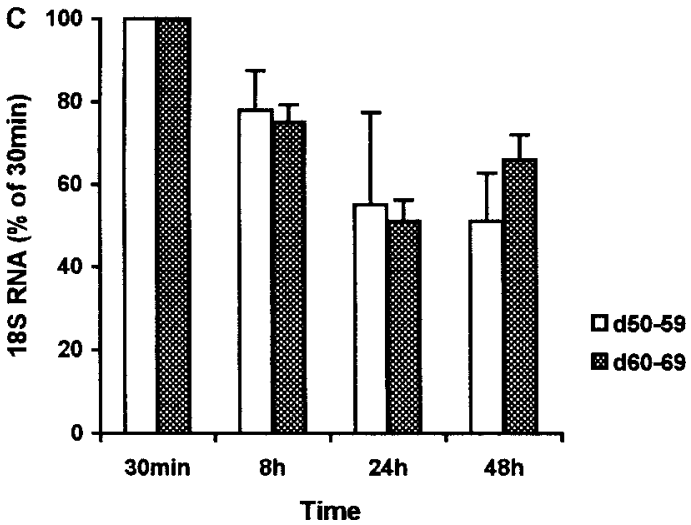

Figure 2 (A) Representative Northern blot showing oCS mRNA in ovine cotyledonary cells collected from a placenta on day 54 of gestation. Total RNA ( $20 \mu \mathrm{g}$ per lane) of cells cultured during $30 \mathrm{~min}, 8 \mathrm{~h}, 24 \mathrm{~h}$ and $48 \mathrm{~h}$ was hybridised with oCS cDNA (time of exposure $=36 \mathrm{~h}$ ) and $18 \mathrm{~S}$ ribosomal cDNA probes (time of exposure $=6 \mathrm{~h}$ ). (B) Quantification of hybridisation signals for oCS mRNA at $30 \mathrm{~min}, 8 \mathrm{~h}, 24 \mathrm{~h}$ and $48 \mathrm{~h}$ of culture, in the ovine cotyledonary cells collected from placentae between d54 and d69 of gestation $(n=7)$. The relative levels of oCS mRNA/18S RNA were determined from STORM scanning of Northern blot membranes. (C) Evolution of 18S RNA during culture time. Values (means \pm S.E.M.) were obtained from STORM scanning of Northern blot membranes $(n=7)$ and are expressed as the percentage of the $18 \mathrm{~S}$ RNA levels at $30 \mathrm{~min}$ of culture. 


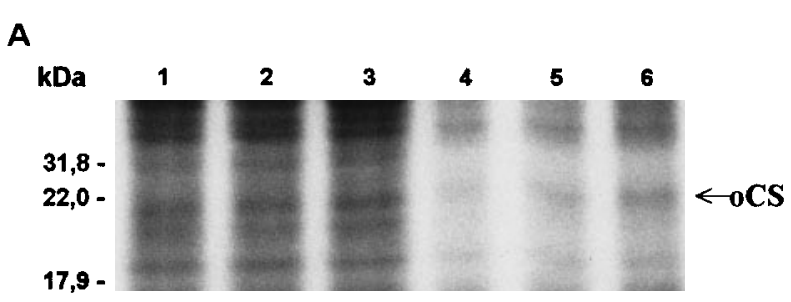

B

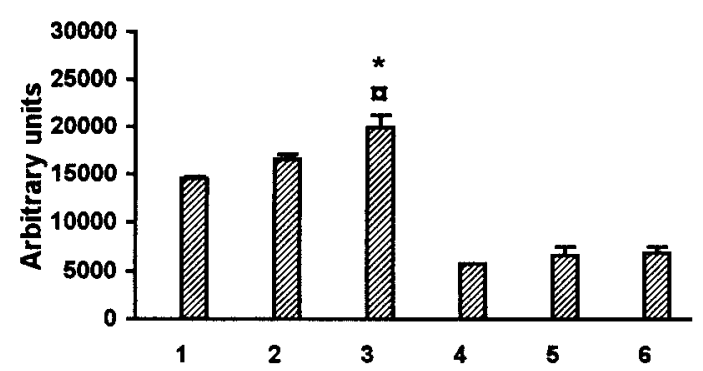

Figure 3 Incorporation of $\left[{ }^{35}\right.$ S $]$ methionine- $\left[{ }^{35}\right.$ S $]$ cysteine in the oCS by ovine cotyledonary cells collected from a placenta on day 75 of gestation: effect of addition of roCS (100 and $300 \mathrm{ng} / \mathrm{ml}$ ). (A) The figure shows a representative autoradiograph of labelled oCS from medium (72 h of culture; control, lane 1; oCS $100 \mathrm{ng} / \mathrm{ml}$, lane 2; oCS $300 \mathrm{ng} / \mathrm{ml}$, lane 3) and cellular content (24 h of culture; control, lane 4; oCS $100 \mathrm{ng} / \mathrm{ml}$, lane 5; oCS $300 \mathrm{ng} / \mathrm{ml}$, lane 6). Labelled oCS was immunoprecipitated with a specific anti-oCS gamma globulin. Control unlabelled roCS stained with Coomassie blue (not shown) migrated as radiolabelled immunoprecipitated oCS in a 16\% SDS-PAGE. (B) Quantification of signals was obtained from STORM scanning of the gels. Values represent the means \pm S.E.M. of 3 experiments on day 75 of gestation. The symbols represent a significant difference $(P<0 \cdot 05)$ between: (ð) $300 \mathrm{ng} / \mathrm{ml}$ roCS-treated cultures vs controls; (*) $100 \mathrm{ng} / \mathrm{ml}$ vs $300 \mathrm{ng} / \mathrm{ml}$ roCS-treated cultures.

to the period of pregnancy when the roCS effect was maximal. A high individual variability between animals at a similar stage was observed in oCS mRNA accumulation. The levels of oCS mRNA presented a trend of being enhanced at $30 \mathrm{~min}$ (for $300 \mathrm{ng} / \mathrm{ml}$ ) or $8 \mathrm{~h}$ of culture compared with controls by d54-d56 of gestation for both roCS doses used. However, it was not significant and no difference at all was observed after this gestational stage.

Effects of roGH addition on cotyledonary cells in culture Incubation of cotyledonary cells collected from placentae between $\mathrm{d} 54$ and $\mathrm{d} 86$ of gestation $(n=6)$, in the presence of 10 or $50 \mathrm{ng} / \mathrm{ml}$ roGH for up to $72 \mathrm{~h}$, had no effect on oCS concentrations within the media and cellular content (not shown).

\section{Discussion}

The results of the present study demonstrate that cotyledonary cells isolated from sheep placentae between
40 to 90 days of gestation, and incubated in vitro during $72 \mathrm{~h}$, exhibited a capacity to produce oCS that increased gradually with pregnancy stage. The levels of this production at each stage studied were related to the oCS cellular content at the time when cultures were started. The oCS accumulation in conditioned medium increased during a long culture period. However, the more important production rate was observed at the end of the first $24 \mathrm{~h}$ of culture, probably due to a better cellular differentiation at this time than later on. In spite of a great variability in hormone production observed between placental cell preparations even at the same period of gestation, a similar pattern of oCS production was observed for all stages studied in these culture conditions. Although cellular adhesion and multiplication were not observed in our culture system, the capacity of cells to produce oCS was supported by several pieces of evidence: levels of the cellular content of oCS were more elevated at $8 \mathrm{~h}$ of culture compared with time zero; both incorporation of $\left[{ }^{35} \mathrm{~S}\right]$ methionine- $\left[{ }^{35} \mathrm{~S}\right]$ cysteine in the oCS protein and oCS mRNA expression were detected during the culture period.

The capacity of cotyledonary cells to produce oCS increased gradually with the stage of pregnancy. The present technique used in our laboratory did not allow us to estimate the percentage of binucleate cells in the preparation, but we observed in our experiments that, for the same number of viable cells, the cellular content of oCS at time zero of culture increased with stage of gestation. This observation could be the consequence of an increase in the number of binucleate cells late in gestation, as suggested by Kappes and coworkers (1992). Moreover, the contribution of oCS cellular content at time zero to total oCS production measured at $72 \mathrm{~h}$ (addition of medium and cellular content at this time) was evaluated at each stage studied. In early stages (d40-49; d50-59) this contribution accounted for $40 \%$ of total oCS production, while it accounted for only $29 \%$ in later stages. These two observations suggest that the individual cellular capacity to produce oCS was increased during the late stages of pregnancy.

Kappes and coworkers (1992) showed a gradual increase in oCS mRNA expression by ovine cotyledonary tissues from placentae collected between d60 and d120 of gestation. In our experiments we analysed oCS mRNA levels in cotyledonary cells $24 \mathrm{~h}$ after dispersion. These levels varied considerably among cell preparations and no significant difference was observed between placentae from d54 to d70 of gestation in spite of increased oCS production. This difference between both studies may result from a relative degradation of mRNA in our culture conditions compared with those observed when mRNA is directly extracted from fresh tissue. Equilibrium between RNases and their inhibitors plays a role in the regulated turnover of mRNA and protein synthesis in the human placenta (Gileadi et al. 1984). It is possible that this 

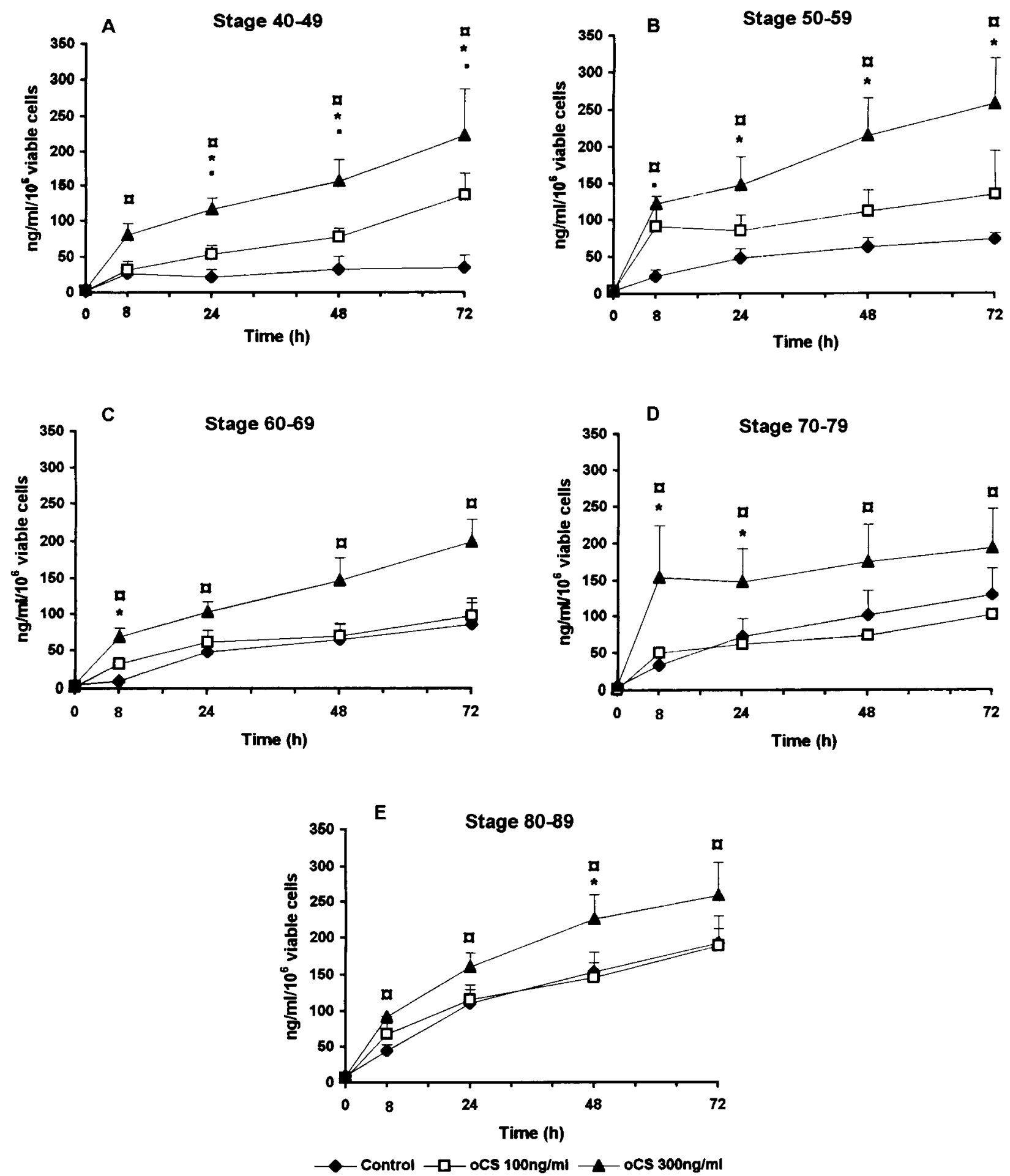

Figure 4 Effect of addition of roCS (100 and $300 \mathrm{ng} / \mathrm{ml})$ to culture medium on oCS release by ovine cotyledonary cells collected from placentae of different periods of gestation: (A) d40-49 ( $n=4)$, (B) d50-59 ( $n=4),(C) \mathrm{d} 60-69$ ( $n=7)$, (D) d70-79 ( $n=7)$ and (E) d80-89 $(n=6)$. The cells were cultured as described in Materials and Methods. Values represent the means \pm S.E.M. of oCS concentrations $\left(\mathrm{ng} / \mathrm{ml} / 10^{6}\right.$ viable cells) accumulated in the medium at different times of culture. The symbols represent a significant difference $(P<0 \cdot 05)$

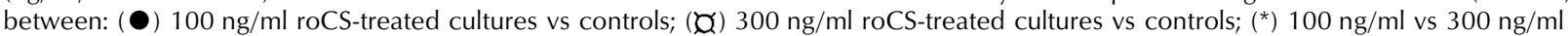
roCS-treated cultures. 


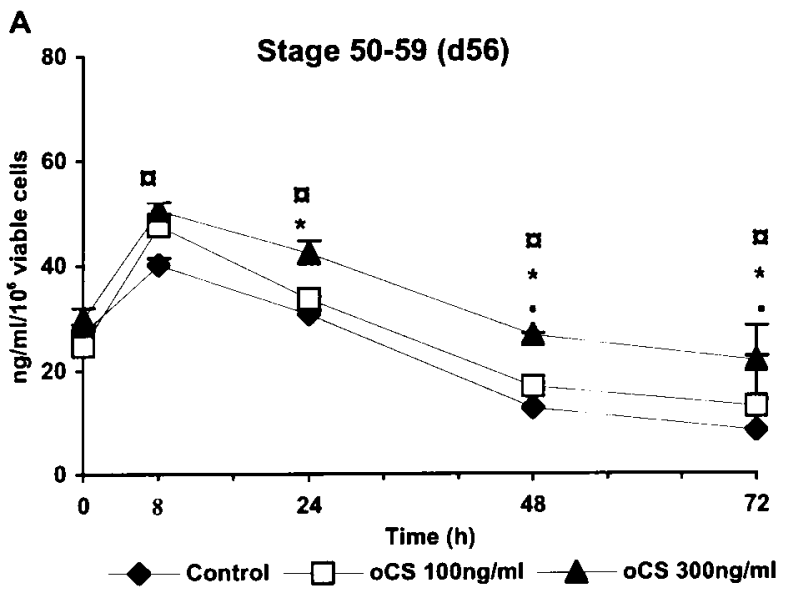

Stage 50-59 (d54)

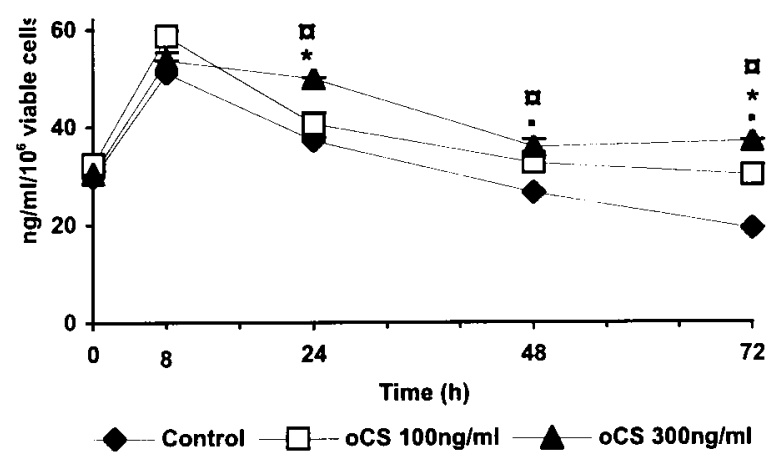

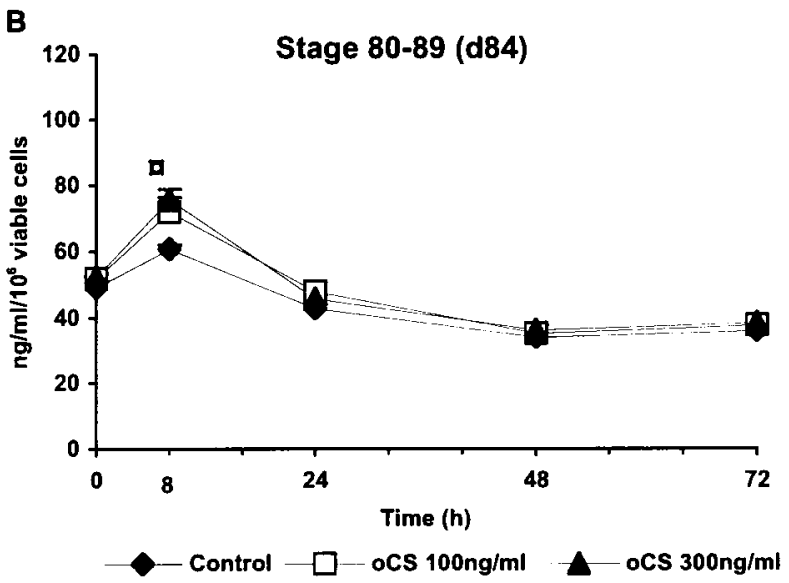

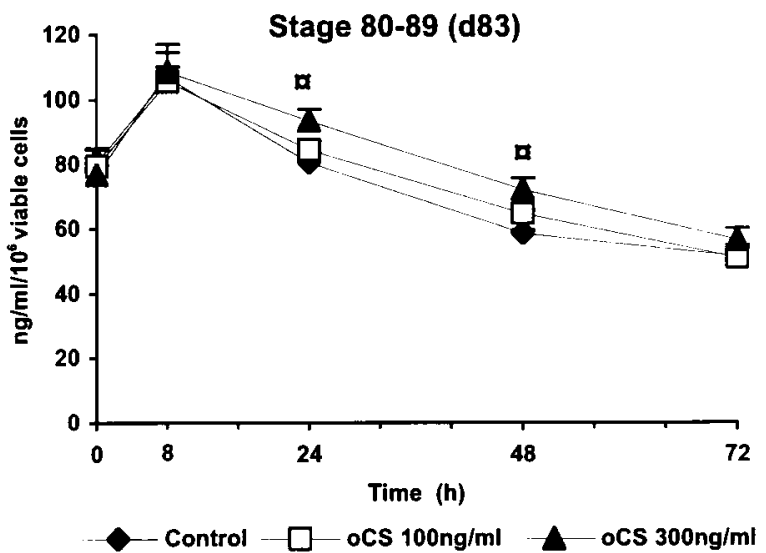

Figure 5 Effect of addition of roCS (100 and $300 \mathrm{ng} / \mathrm{ml})$ on oCS cellular content in ovine cotyledonary cells. The figure shows 4 representative individual experiments: (A) d50-59 $(n=2)$ and (B) d80-89 $(n=2)$ of gestation. The effects of roCS treatment on the early stage were observed in spite of the great variability between animals in the oCS cellular content of control cells. The cells were cultured as described in Materials and Methods and values represent the means \pm S.E.M. of oCS cellular content concentrations (ng/ml $/ 10^{6}$ viable cells) at different times of culture. The symbols represent a significant difference $(P<0 \cdot 05)$ between: $(\bullet) 100 \mathrm{ng} / \mathrm{ml}$ roCS-treated cultures vs controls; (ðð) $300 \mathrm{ng} / \mathrm{ml}$ roCS-treated cultures vs controls; $\left(^{*}\right) 100 \mathrm{ng} / \mathrm{ml}$ vs $300 \mathrm{ng} / \mathrm{ml}$ roCS-treated cultures.

equilibrium was altered when ovine cotyledonary cells were isolated. We cannot exclude the possibility that mRNA degradation was a consequence of cellular death. However, the slope of the decrease in mRNA is steeper than that of viability of cells (not shown).

The addition of roCS in the culture medium increased the endogenous oCS net production in a dose-dependent manner. This effect was more important in early stages than in later stages. The content of oCS in cells at the beginning of the cultures seemed to be, in part, a limiting factor to roCS stimulation: when this content was low (in the early stages of gestation) the enhancement of oCS production by the addition of roCS was more efficient than when it was high (d70 to d90). The $100 \mathrm{ng} / \mathrm{ml}$ dose of recombinant hormone was not effective in stimulating oCS production of cells collected after d60. However, the $300 \mathrm{ng} / \mathrm{ml}$ dose was always efficient, but less potent on cells collected during the late periods of gestation studied. The cells collected during these late stages of gestation could already be in a stimulated state due to the elevated endogenous levels of oCS in this endocrine environment. Moreover, the enhancement of incorporation of $\left[{ }^{35} \mathrm{~S}\right]$ methionine-cysteine after addition of roCS is in favour of stimulation of neosynthesis.

These results allowed us to suggest that oCS up-regulates its own production via an autocrine and/or paracrine mechanism. Such mechanisms of autoregulation have been observed in many hormonal systems. Although these autoregulatory responses are often relevant from the perspective of down-regulation (Wei et al. 1988, Sanchez-Pacheco et al. 1995), hormone-mediated upregulation has also been documented (Jia \& Hsueh 1984, Bagnato et al. 1991, Peng et al. 1994). A system of autoregulation has been identified in human placenta for 
human chorionic gonadotrophin (Licht et al. 1993). This up-regulated oCS system may contribute to an adequate growth and development of ovine placenta. It could be, in part, responsible for the morphological and/or functional differentiation in trophoblast cells during placental growth.

In early pregnancy (d54-56), regulation of the oCS production was concomitant with a slight although not significant increase in oCS mRNA accumulation. We impute this lack of significance to the high variability of oCS mRNA measurement between animals at these stages of pregnancy. This trend could result from a transcriptional effect of roCS or from a less important degradation of oCS mRNA in treated cells in the presence of recombinant hormone at this stage. However, more studies need to be conducted to validate definitively these hypotheses. Furthermore, we suggest that roCS autoregulation also involves posttranscriptional mechanisms, since the roCS effect was observed without a difference in oCS mRNA accumulation in placental cells collected between d60 and d69 of gestation.

The effect of addition of roCS on endogenous oCS production by cotyledonary cells in vitro, modulated by stage of gestation, is concomitant with the period of maximum development and growth of placenta (Reynolds et al. 1996). Therefore, we suggest that oCS plays an important role in cotyledonary cell differentiation which occurs in vivo during the same period.

The interaction of oCS and oGH with a common receptor has been suggested (Klempt et al. 1993, Breier et al. 1994). Furthermore, GH receptor mRNA has been described in the ovine placenta (Klempt et al. 1993). However, our results showed that autoregulation of oCS production could not be mimicked by the addition of roGH to cells collected from placentae between d54 and d86 of gestation. Binding of oCS to a specific receptor has been proposed (Freemark et al. 1986, 1987, 1988, Freemark \& Comer 1989, Pratt et al. 1995) and an oCS receptor has been identified in ovine placenta (Chan et al. 1978a). Our results suggest the presence of a specific receptor for oCS in ovine placenta.

\section{References}

Bagnato A, Moretti C, Frajese G \& Catt KJ 1991 Gonadotropininduced expression of receptors for growth hormone releasing factor in cultured granulosa cells. Endocrinology 128 2889-2894.

Battista PJ, Bell AW, Deaver DR \& Currie WB 1990 Differential control of placental lactogen release and progesterone production by ovine placental tissue in vitro. Placenta 11 337-348.

Breier BH, Funck B, Surus A, Ambler GR, Wells CA, Waters MJ \& Gluckman PD 1994 Characterisation of ovine growth hormone $(\mathrm{oGH})$ and ovine placental lactogen (oPL) binding to fetal and adult hepatic tissue in sheep: evidence that oGH and oPL interact with a common receptor. Endocrinology 135 919-928.

Brinsmead MW, Bancroft BJ, Thorburn GD \& Waters MJ 1981 Fetal and maternal ovine placental lactogen during hypoglycaemia and fasting. Journal of Endocrinology 90 337-343.
Chamberlain JP 1979 Fluorographic detection of radioactivity in polyacrylamide gels with the water-soluble fluor, sodium salicylate. Analytical Biochemistry 98 132-135.

Chan JSD, Robertson HA \& Friesen HG 1978a Distribution of binding sites for ovine placental lactogen in the sheep. Endocrinology 102 632-640.

Chan JSD, Robertson HA \& Friesen HG 1978 b Maternal and fetal concentrations of oPL measured by radioimmunoassay. Endocrinology 102 1606-1613.

Chomczynski P \& Sacchi N 1987 Single-step method of RNA isolation by acid guanidinium thiocyanate-phenol-chloroform extraction. Analytical Biochemistry 162 156-159.

Colosi P, Thordarson G, Hellmiss R, Singh K, Forsyth IA, Gluckman P \& Wood WI 1989 Cloning and expression of ovine placental lactogen. Molecular Endocrinology 3 1462-1469.

Fowlkes J \& Freemark M 1992 Binding of placental lactogen and growth hormone to fetal sheep fibroblasts. Pediatric Research 32 200-203.

Freemark M, Comer M \& Handwerger S 1986 Placental lactogen and GH receptors in sheep liver: striking differences in ontogeny and function. American Journal of Physiology 251 E328-E333.

Freemark M, Comer M, Korner G \& Handwerger S 1987 A unique placental lactogen receptor: implication for fetal growth. Endocrinology 120 1865-1872.

Freemark M, Comer M \& Korner G 1988 Differential solubilization of placental lactogen (PL)- and growth hormone-binding sites: further evidence for a unique PL receptor in fetal and maternal liver. Endocrinology 122 2771-2779.

Freemark M \& Comer M 1989 Purification of a distinct placental lactogen receptor, a new member of the growth hormone/prolactin receptor family. Journal of Clinical Investigation 83 883-889.

Gileadi O, Loberboum H, Groot N \& Hochberg AA 1984 Location of RNase and RNase inhibitor on free cytoplasmic mRNA-protein particles from human placenta. Molecular Biology Reports 9 241-244.

Gluckman PD \& Barry TN 1988 Relationships between plasma concentrations of placental lactogen, insulin-like growth factors, metabolites and lamb size in late gestation ewes subject to nutritional supplementation and in their lambs at birth. Domestic Animal Endocrinology 5 209-217.

Gluckman PD, Kaplan SL, Rudolph AM \& Grumbach MM 1979 Hormone ontogeny in the ovine fetus. II. Ovine chorionic somatomammotropin in mid and late gestation in the fetal and maternal circulation. Endocrinology 104 1828-1834.

Grandis A, Jorgensen V, Kodack L, Quarfordt S \& Handwerger S 1989 High density lipoproteins (HDL) stimulate placental lactogen secretion in pregnant ewes: further evidence for a role of HDL in placental lactogen secretion during gestation. Journal of Endocrinology 120 423-427.

Handwerger S, Maurer WF, Barrett J, Hurley TW, Golander A \& Fellows RE 1974 Evidence for homology between ovine and human placental lactogens. Endocrine Research Communications 1 403-413.

Handwerger S, Crenshaw C, Maurer WF, Barrett J, Hurley TW, Golander A \& Fellows RE 1977 Studies on ovine placental lactogen secretion by homologous radioimmunoassay. Journal of Endocrinology 72 27-34.

Handwerger S, Crenshaw MC, Lansing A, Golander A, Hurley TW \& Fellows RE 1978 Stimulation of ovine placental lactogen secretion by arginine infusion. Endocrinology 103 1752-1758.

Huyler SE, Butler WR, Grandis A, Mann C, Figueroa JP, Nathanielsz PW, Mitchell M \& Handwerger S 1985 Stimulation of ovine placental lactogen secretion by arachidonic acid. Journal of Endocrinology 106 43-47.

Jia XC \& Hsueh AJ 1984 Homologous regulation of hormone receptors: luteinizing hormone increases its own receptors in cultured rat granulosa cells. Endocrinology 115 2433-2439. 
Kappes SM, Warren WC, Pratt SL, Liang R \& Anthony RV 1992 Quantification and cellular localisation of ovine placental lactogen messenger ribonucleic acid expression during mid and late gestation. Endocrinology 131 2829-2838.

Klempt M, Bingham B, Breier BH, Baumbach WR \& Gluckman PD 1993 Tissue distribution and ontogeny of growth hormone receptor messenger ribonucleic acid and ligand binding to hepatic tissue in the mid gestation sheep fetus. Endocrinology 132 1071-1077.

Lacroix MC, Devinoy E, Servely JL, Puissant C \& Kann G 1996 Expression of the growth hormone gene in ovine placenta: detection and cellular localisation of the protein. Endocrinology 137 4886-4892.

Lee CS, Wooding FPB \& Brandon M R 1986 Ultrastructural immunogold investigation of the function and diversity of binucleate cells in the ovine placenta using a monoclonal antibody. Placenta 7 495-504.

Licht P, Cao H, Lei ZM, Rao CV \& Merz WE 1993 Novel self-regulation of human chorionic gonadotropin biosynthesis in term pregnancy human placenta. Endocrinology 133 3014-3025.

Martal J \& Djiane J 1975 Purification of a lactogenic hormone in sheep placenta. Biochemical and Biophysical Research Communications $65770-778$.

Martal J \& Djiane J 1977 The production of chorionic somatomammotropin in sheep. Journal of Reproduction and Fertility 49 285-289.

Moore GPM, Panaretto BA \& Wallace ALC 1984 Treatment of ewes at different stages of pregnancy with epidermal growth factor: effects on wool growth and plasma concentrations of growth hormone, prolactin, placental lactogen and thyroxin and on fetal development. Acta Endocrinologica 105 558-566.

Morgan G, White A \& Wooding FBP 1990 Characterisation of the synthetic capacities of isolated placental binucleated cells from sheep and goat. Anatomical Record 226 27-36.

Peng C, Fan NC, Ligier M, Vaananen J \& Leung PC 1994 Expression and regulation of gonadotropin-releasing hormone $(\mathrm{GnRH})$ and $\mathrm{GnRH}$ receptor messenger ribonucleic acids in human granulosa-luteal cells. Endocrinology 135 1740-1746.

Peterson GL 1977 A simplification of the protein assay method of Lowry et al. which is more generally applicable. Analytical Biochemistry 83 346-356.

Pratt SL, Kappes SM \& Anthony RV 1995 Ontogeny of a specific high-affinity binding site for ovine placental lactogen in fetal and postnatal liver. Domestic Animal Endocrinology 12 337-347.

Puissant C \& Houdebine LM 1990 An improvement of the single-step method of RNA isolation by acid guanidinium thiocyanate-phenolchloroform extraction. Biotechniques 8 148-149.

Raynal F, Michot B \& Bachellerie JP 1984 Complete nucleotide sequence of mouse $18 \mathrm{~S}$ rRNA gene: comparison with other available homologs. FEBS Letters 167 263-268.

Reynolds TS, Stevenson KR \& Wathes D 1997 Pregnancy-specific alterations in the expression of the insulin-like growth factor system during early placental development in the ewe. Endocrinology 138 886-897.

Rhodes R, Cowan RG, Nathanielsz PW \& Reimers TJ 1986 Production of progesterone and placental lactogen (oPL) by ovine binucleate trophoblastic cells (BNTC). Biology of Reproduction 34 (Suppl 1) Abstract 63.
Rice GE \& Thorburn GD 1986 Stimulation of ovine choriomammotrophin release, in vitro, by phospholipase C. Placenta 7 533-542.

Sakal E, Bignon C, Grosclaude J, Kantor A, Shapira R, Leibovitch H, Helman D, Nespoulous C, Shamay A, Rowlinson SW, Djiane J \& Gertler A 1997 Large-scale preparation and characterisation of recombinant ovine placental lactogen. Journal of Endocrinology 152 317-327.

Sanchez-Pacheco A, Palomino T \& Aranda A 1995 Negative regulation of expression of the pituitary-specific transcription factor GHF-1/Pit-1 by thyroid hormones through interference with promoter enhancer elements. Molecular Cellular Biology 15 6322-6330.

SAS Institute Inc., SAS/STAT Software 1997 Changes and Enhancements through Release 6.12. Cary, NC: SAS Institute Inc.

Schoknecht PA, Nobrega SN, Petterson JA, Ehrhardt RA, Slepetis R \& Bell AW 1991 Relations between maternal and fetal plasma concentrations of placental lactogen and placental and fetal weights in well-fed ewes. Journal of Animal Science 69 1059-1063.

Schoknecht PA, Currie WB \& Bell AW 1992 Kinetics of placental lactogen in mid- and late-gestation ovine fetuses. Journal of Endocrinology 133 95-100.

Schoknecht PA, McGuire MA, Cohick WS, Currie WB \& Bell AW 1996 Effect of chronic infusion of placental lactogen on ovine fetal growth in late gestation. Domestic Animal Endocrinology 13 519-528.

Servely JL, Emane MN, Houdebine LM, Djiane J, Delouis C \& Kelly PA 1983 Comparative measurement of the lactogenic activity of ovine placental lactogen in rabbit and ewe mammary gland. General and Comparative Endocrinology 51 255-261.

Singh K, Ambler GR, Breier BH, Klempt M \& Gluckman PD 1992 Ovine placental lactogen is a potent somatogen in the growth hormone (GH)-deficient rat: comparison of somatogenic activity with bovine GH. Endocrinology 130 2758-2766.

Steven DH, Mallon KA \& Nathanielsz PW 1980 Sheep trophoblast in monolayer cell culture. Placenta 1 209-221.

Taylor MJ, Jenkin G, Robinson JS, Thorburn GD, Friesen H \& Chan JSD 1980 Concentrations of placental lactogen in chronically catheterised ewes and fetuses in late pregnancy. Journal of Endocrinology 85 27-34.

Warren WC, Liang R, Krivi GG, Siegel NR \& Anthony RV 1990 Purification and structural characterisation of ovine placental lactogen. Journal of Endocrinology 126 141-149.

Wei LL, Krett NL, Francis MD, Gordon DF, Wood WM, O'Malley BW \& Horwitz KB 1988 Multiple human progesterone receptor messenger ribonucleic acids and their autoregulation by progestin agonists and antagonists in breast cancer cells. Molecular Endocrinology $262-72$.

Wooding FPB 1981 Localization of ovine placental lactogen in sheep placentomes by electron microscope immunocytochemistry. Journal of Reproduction and Fertility 62 15-19.

Received 14 August 1998

Revised manuscript received 16 November 1998 Accepted 5 January 1999 